\title{
A UNIQUE REPRESENTATION OF A WOMAN IN THE SCENES OF STATUE MANUFACTURE
}

\author{
MOHAMED I. ABOUELATA \\ Collage of Tourism and Archaeology, King Saud University, KSA \\ Faculty of Archaeology, Fayoum University, Egypt \\ E-mail: abolattaa@yahoo.com
}

\begin{abstract}
The tomb of Baqet III (No. 15) at Beni Hassan contains four scenes which depict different stages of the manufacture of the statues. One of these scenes, on the northern wall, depicts an artisan painting a statue in the final stages of the manufacture. Behind the statue, there is a woman, who holds with her right hand the right wrist of the statue, while her left hand disappears behind the shoulders of the statue. Because of the depiction of this woman, this scene is a unique one among all the scenes that show the manufacture of the statues in all periods of Egyptian history. The scene lacks a text or a caption that defines the personality of the woman, or clarifies her role in the scene. A comparative study has been examined here on the scenes of the statue manufacture which are depicted in Egyptian tombs in order to identify that woman and her role.
\end{abstract}

KEYWORDS

Egyptian Statuary- Artisan- Beni HassanBaqet- Private Tombs

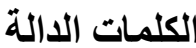

أتضمن مقبرة باقت في بنى حسن (رقم 15)

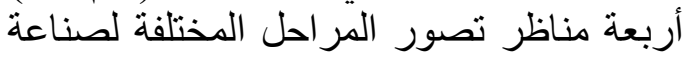

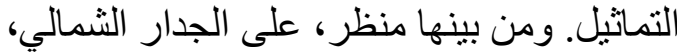
يصور أحد الفنانين يقوم بتلوين التمثنال في التياتي مر احله النهائية، وخلف التمثال تقف سيدة تمسك بيدها اليمنى الرسغ الأيمن للتمثنال بينما تختفي يدها اليسرى خلف كتف التمثال. ويتفرد هذا لئنا المنظر بين كل المناظر التي تضمنت تصني تصوير صناعة التماثيل المصرية في كافة العصور بتصوير سيدة في منظر لصناعة التماثيل. ويفتقد

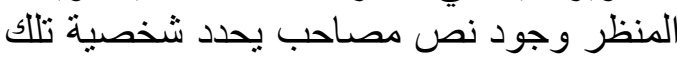

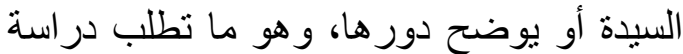
مقارنة مع مناظر صناعة التوفي دورها، التواثيل في المقابر

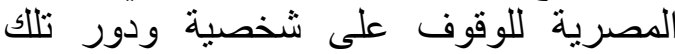
السيدة المشاركة في المنظر. التماثيل المصرية_النحاتون-بني حسن-باقت_مقابر 


\section{INTRODUCTION}

Statues were of great importance in ancient Egypt, especially in religious and funerary beliefs. The ancient Egyptians believed that the statue embodied a dwelling of the soul to settle in, whether it represents a divine or a human being, in order to find a care. Therefore, the statue was the earthly embodiment of the spirit of its owner. ${ }^{1}$ The soul got benefits from the prayers and sacrifices offered to the statue, which was only an intermediary between the living and the god or the dead. ${ }^{2}$ Therefore, the Egyptian statues were placed in temples and tombs to substitute the souls that settled in them or came to them at certain times. Through the opening of the mouth ritual, statues can practice life and receive the offerings and prayers offered to them. ${ }^{3}$

This influential belief in ancient Egyptian thoughts, made the Egyptians produced statues from the early beginning of their civilizations. Prehistoric cultures produced the first large stone statues in Egyptian civilization. ${ }^{4}$ The terracotta statues were known from the Merimde culture. $^{5}$ Therefore, the creative development in the Egyptian statues was very fast. Because of the great importance of statues, Egyptian civilization produced more statues than any other ancient civilization. ${ }^{6}$ The availability of raw material, which was used in the manufacture of the statues, was not the main reason for this abundance of statues, but it was the religious motive. ${ }^{7}$

The stages of making the statue are occurred on the scenes of the royal and private tombs, as it was the case with the other crafts and industries. The first attestation of such scenes is probably the scenes which are depicted in the tomb of Queen Mersyankh III at Giza, which dates to the Fourth Dynasty. ${ }^{8}$ Such scenes found its way to the walls of many private tombs throughout the Egyptian history. Among of these scenes is the following scene, which is the subject of this paper.

\section{DESCRIPTION OF THE SCENE}

The scene is shown on the eastern end of the second register on the northern wall of the main hall of the tomb (Fig. 1, 2). ${ }^{9}$ It depicts an artisan sitting on a stool, wearing a short kilt. The left hand of the artisan extends forward, holding a jar including a paint which is used in painting the statue. His right hand raising towards the shoulder of the statue, standing in front of him, holds a brush painting the shoulder or the necklace of the statue. The statue is shown striding forward with his left leg, while his arms stretches along his body, wearing a short kilt which covers the lower part of his body, and a necklace adorning his neck. Behind the statue, there is a woman; represented as usual with two legs side by side, wearing a long tight garment and a wig. Her right arm extends across her body to hold the right arm of the statue at the wrist area, while her left arm appears, at the beginning,

1Kozloff, "Sculpture", 218.

2Price, "On the Function of the 'healing' statues", 174; Lorton, "The Theology of Cult Statues in Ancient Egypt", 138; Finnestad, The meaning and purpose of Opening the Mouth, 118.

3Assmann, Death and salvation in ancient Egypt, 312; Otto, Das Ägyptische Mundöffnungsritual, 2.

4Eaton-Krauss, "Sculpture in Early Dynastic Egypt", 180.

5Eiwanger, Die neolithische Siedlung, 74, pl. 10.

6Kozloff, "Sculpture", 218.

7Kozloff, "Sculpture", 218.

8Eaton-Krauss, Representation of Statuary, 107; Dunham and Simpson, Mersyankh, Figs. 5, 8. 9PM IV, 151 (2-6); Newberry, Beni Hasan, II, pl. iv.

- 65 - A Unique Representation of a Woman in the Scenes of Statue Manufacture 
extending behind the statue shoulder but its end never appeared which suggest that she is supporting the statue with her left hand. The scene lacks any text or caption.

This scene is the one before the last in the second register; it is followed by a single scene which depicts another statue, mostly finished, standing in front of a man. Additionally, this scene is preceded by various scenes in the same register including different activities such as a barber and shaving, a chiropodist, industry scenes, linen spinning and weaving, and scenes of quarrel. ${ }^{1}$ These scenes are accompanied by short texts and captions, but all of them are not related to the scene of painting the statue except that they all are shown in the context of depicting some crafts and daily life activities.

\section{COMPARATIVE STUDY WITH OTHER SCENES OF STATUES MAKING}

In order to determine the character and the role of the woman who stands behind the statue, in this unique scene, it should be compared to the scenes of statue manufacture from different periods.

\section{Comparison with the Old Kingdom scenes}

The mural scenes of the tombs of the Old Kingdom depicted scenes of statuary making among the scenes of everyday life. The earliest known depiction of such scenes is three scenes of the Fourth Dynasty which are shown in the tomb of Mersyankh III at Giza. Two scenes are depicted in the third register of the southern side of the eastern wall in the main hall of the tomb (Fig. 3). ${ }^{2}$ The first scene depicts a standing statue of the queen facing a standing artisan who paints the statue. He holds a paint jar in one hand and a brush in the other. The text, which describes the scene, is not clear now although "Reisner" read it "the painter, Rahay". ${ }^{3}$ The second scene is in front of the first one. It depicts a sitting statue of the queen facing a sculptor whose name is "Yenkaf" shaping the statue with a chisel in his right hand. He is leaning his leg forward in an embodiment pose for the movement of the artisan while sculpting; he steadies himself by putting his free left hand on the lower arm of the statue. ${ }^{4}$ At the western end of the southern wall of the same hall, a third scene depicts a standing statue of the queen (Fig. 4). ${ }^{5}$ In front of it, the artisan stands holding the brush in one hand to paint the chest of the statue while the other hand holds the paint jar. The text describes him as "the painter, Rahay". ${ }^{6}$

The southern wall of the chapel of the tomb of Ti at Saqqara, which dates to the Fifth Dynasty, keeps three scenes out of eight depict making statues. No remains from the other five scenes are kept except the lower ends and part of a scene showing the sculptor working on a statue whose image was lost. ${ }^{7}$ The three remaining scenes depict the manufacture of three statues in different stages (Fig. 5). All these scenes are accompanied by texts which indicate the role of the worker or determine the work itself. The first of these scenes depicts

1Newberry, Beni Hasan, II, 47, pl. iv.

$2 P M$ III, 197 (2); Dunham and Simpson, Mersyankh, 12, Fig. 5.

3Reisner, The Tomb of Meresankh, 79.

4Eaton-Krauss, Representation of Statuary, 110.

5PM III, 197 (3); Dunham and Simpson, Mersyankh, 16, Fig. 8.

6Reisner, The Tomb of Meresankh, 78-9.

7PM III, 473 (36); Wild, Le tombeau de Ti, III, pl. clxxiii.

A Unique Representation of a Woman in the Scenes of Statue Manufacture 
a standing wooden statue while the carpenter, according to the text, sitting behind the statue and shaping its back using an adze in his right hand while his left hand holds the leg of the statue to support it. In front of the statue, the sculptor is shown forming the kilt of the statue using a mallet and chisel. The caption reads "smoothing" the statue. ${ }^{1}$ The second scene depicts a standing statue between two kneeling sculptors; one in front and the other behind, they polish the statue according to the text that reads "polishing by the sculptor". ${ }^{2}$ The third scene depicts a seated statue between two seated sculptors, the one behind the statue polishes the chair on which the statue sits, while the one in front polishes the statue's chest. The text reads "execution of work by the craftsman". ${ }^{3}$

The Sixth Dynasty tomb of Aba (Ibi) in Deir el-Gebrawi contains four scenes of the manufacture of the statues. They are shown on the eastern side of the northern wall of the main hall. ${ }^{4}$ The first scene, in the upper register (Fig. 6), depicts a statue sitting on a stool facing a standing sculptor who shapes the statue with a chisel in one hand and a lost hammer in the other. The text reads "a sculpture chiseling a statue". ${ }^{5}$ The other three scenes are depicted in the second register of the same wall (Fig. 7). At the second scene, the sculptor shapes a standing statue that is represented with his two legs side by side. This gesture together with the hairstyle indicates that she is a female, although the statue is painted in red, the preferred colour for the male bodies. It should be noticed that some female figures in this tomb coloured in orange approaching red. ${ }^{6}$ The third scene depicts the sculptor shaping a statue in the shape of a lion rather than the form of the sphinx. The statue was depicted with a full body and face of a lion. The last scene depicts a standing statue. The artisan, who sits before, paints it. The text reads "adorning the face of the statue". 7

At the same necropolis of Deir el-Gebrawi, the tomb of Zau of the Sixth Dynasty contains the remains of scenes depicting at least the manufacture of two statues at the eastern end of the upper register of the northern wall of the main hall. The scenes also includes a third finished statue which represents a woman ${ }^{8}$ (Fig. 8). The remains of the first scene shows the feet of a standing statue without a base, while the gesture of the seated artisan suggests that he paints the statue. The second scene, which depicts a headless seated statue, shows the sculptor standing behind the statue shaping it with an adze in his hand, while in front of the statue another standing sculptor is represented working on the statue using a hammer and a chisel. The accompanying text reads "adorning the statue by the sculptor". 9 The third scene, which depicts a standing statue of a woman, does represent her in profile posture.

1Eaton-Krauss, Representation of Statuary, 126, Cat. No. 28, pl. iv, 28; Wild, Le tombeau de Ti, III, pl. clxxiii.

2Eaton-Krauss, Representation of Statuary, 125, Cat. No. 27, pl. iv, 27; Wild, Le Tombeau de Ti, III, pl. clxxiii.

3Eaton-Krauss, Representation of Statuary, 125, Cat. No. 26, pl. iv, 26; Wild, Le Tombeau de Ti, III, pl. clxxiii.

$4 P M$ IV, 244 (12-13); Davies, Deir El Gebrawi, I, pl. xiv.

5Davies, Deir El Gebrawi, I, 19, pl. xiv; Eaton-Krauss, Representation of Statuary, 136, Cat. No. 48, pl. vii, 48.

6 Davies, Deir El Gebrawi, I, p.19, pl. xiv; Eaton-Krauss, Representation of Statuary, 137, Cat. No. 50, pl. vii, 50 .

7 Davies, Deir El Gebrawi, I, 19, pl. xiv.

8 PM, IV, 245 (8), Davies, Deir El Gebrawi, II, pl. x; Eaton-Krauss, Representation of Statuary, 137-9, Cat. Nos. 51-53, pl. vii, 51-53.

9 Eaton-Krauss, Representation of Statuary, 138, Cat. No. 52, pl. vii, 52.

- 67 - A Unique Representation of a Woman in the Scenes of Statue Manufacture 
Her outer arm stretched out along the body, while the inner hand holds a papyrus scepter. The statue is depicted without a base. ${ }^{1}$

\section{Comparison with the Middle Kingdom scenes}

The tomb of Baqet III includes four scenes of statue manufacture. All of them are depicted on the northern wall of the main hall of the tomb. The first of these four scenes is this study scene, shows a woman behind a statue, which is depicted before the end of the second upper register. The second is a scene at the end of the same register, adjacent to this study scene (Fig. 2). It includes a mostly finished standing statue, supported by a back pillar. The statue probably represents a child, according to the attitude of his right hand raising towards his mouth, which is one of common gestures representing childhood. ${ }^{2}$ In front of the statue, a person stands who is most probably an artisan. The third scene in this tomb is shown before the end of the fifth register (Fig. 9). ${ }^{3}$ It represents a standing artisan who paints a standing statue. This statue is depicted wearing a short pointed kilt. The fourth scene is located at the eastern end of the fifth register next to the previous scene (Fig. 9). ${ }^{4}$ It depicts a statue during the sculpture process. The sculptor is shown chiseling the statue's arm using a chisel and a hammer. In the last three scenes, unlike the first scene, the artisan was shown with the statue without a woman. In each scene, the artisan performed a different work. The role of the artisan in the second scene is not clear. In the third, he is painting the statue as in the first scene; the difference between these two scenes is that the artisan is shown standing in the third scene while seated in the first. In the fourth scene, he is sculpting the statue.

Middle Kingdom tombs at Beni Hassan show some more scenes of manufacturing the statues. The tomb of Khety (No. 17) includes two scenes for the manufacture of the statue which they are very similar to the last two scenes in the tomb of Baqet III above. One of them depicts an artisan who paints a statue and the other one depicts a sculptor chiseling a statue (Fig. 10). ${ }^{5}$ The tomb of Khnumhotep (No. 3), at Beni Hassan, shows a scene depicting a sculptor polishing a statue using a stone tool ${ }^{6}$ (Fig. 11).

\section{Comparison with the New Kingdom scenes}

From the New Kingdom, the tomb of Rekhmire (TT 100) of the Eighteenth Dynasty, at Sheikh Abd el-Qurna, contains three scenes depicting three royal statues in the final stage of the manufacture. These scenes are depicted on the eastern part of the southern wall of the passage. They show the sculptors and artisans finalizes the sculptured statues ${ }^{7}$ (Fig. 12). One of the scenes depicts five sculptors working on a standing statue of the King Thutmosis III. One of them polishes the crown, the second polishes the chest area, while the third polishes the foot, the fourth and fifth inscribes and working on the back pillar respectively. The second scene shows three of the sculptors working on finishing a statue

\footnotetext{
1 Eaton-Krauss, Representation of Statuary, 138, Cat. No. 53, pl. vii, 53.

2 Robins, The Art of Ancient Egypt, 72; Tefnin, "Private Sculpture", 241.

3 Newberry, Beni Hasan, II, 47, pl. iv.

4 Newberry, Beni Hasan, II, 47, pl. iv.

5 Newberry, Beni Hasan, II, 57, pl. xiii.

6 Newberry, Beni Hasan, I, pl. xxix.

7 PM I.1, 211 (14, vi); Davies, The Tomb of Rekh-mi-re, 58-9, pl. 1x.
}

A Unique Representation of a Woman in the Scenes of Statue Manufacture $\mid \mathbf{- 6 8}$ - 
for the king in the posture of sphinx. The third scene depicts three of the sculptors making a seated statue for the king. ${ }^{1}$

All these previous scenes, from the Old, Middle, and New Kingdoms, vary concerning the existence of captions or explanatory texts. Some of them contain texts explaining the action practiced by the sculptor or the artisan, depicted in the scene, such as polishing in the tomb of Ti, decorating in the tomb of Aba. Some others refer only to the craft of the workman, without specifying his actual role, such as "the sculptor" in the tombs of Baqet III and Khety. Some others lacks the existence of any text, specifying the character or the role of the individuals depicted working on the statues. Among these scenes is the scene of this paper, which has a unique depiction for a woman appeared in a manufacture scene. Thus, in the absence of the text and the presence of the woman, the question arises about the character and the role of that woman depicted in the scene of the tomb of Baqat III.

\section{INTERPRETING THE CHARACTER OF THE WOMAN}

This study assumes and discuses three possible hypothetical interpretations for the character of this woman and her role. The first hypothesis considers the scene depicting the manufacture of a pair statue of the tomb owner and his wife. It is based on; the depiction of the statue manufacture in mural scenes of a tomb clearly indicates that the statue belongs to the owner of the tomb ${ }^{2}$ and no one was represented with a statue except a member of his family, or a deity for the ruler. Since this study scene contains only Baqet III and that woman, it might be interpreted that the sculptor may have been working on a dyad statue, which always representing a husband and wife.

This point of view could be supported by the fact that the woman is represented in the same size to of the man, which may reflect her position and importance for him. Additionally, her dress is somewhat similar, in its general form, to the dress of the wife of Baqet III, who was depicted behind him in a scene at the beginning of this northern wall (Fig. 1). This proposition is also supported by finding several pair statues representing a husband and wife, in a situation that reflects the family ties of affection, since the Old Kingdom. ${ }^{3}$

This point of view is plausible, but the right arm of the woman is depicted in a medium position between the vertical and the horizontal, creating a position that cuts the woman's body. This position of arm was not found in the private family statues, despite the large number of such statues which were attested representing the relationship between the husband and his wife or among the whole family members even in the presence of children. This position also contrasts with the religious and artistic belief that avoid hiding the body or representing it in a position shows its imperfection so as does not effect on the body at the resurrection. ${ }^{4}$ This position of the arm could also make the statue vulnerable to be broken. The ancient Egyptian sculptor was very keen to portray the body in a full image, although this attention, the Egyptian royal and non-royal statues were sculptured with the arm stretches across the body hiding partially the body or the arm is hidden behind it. For example, the standing royal dyad statues of Menkaure and his wife (Boston MFA,

1 Davies, The Tomb of Rekh-mi-re, 59.

2 Drenkhahn, Die Handwerker, 56.

3 Ziegler, "Nonroyal Statuary", 62, Figs on pages 290-94.

4 Davis, "Scale and Pictoriality in Ancient Egyptian Painting and Sculpture", 277; Kozloff, "Sculpture", 219; Robins, The Art of Ancient Egypt, 19.

- 69 - A Unique Representation of a Woman in the Scenes of Statue Manufacture 
11.1738), ${ }^{1}$ (Fig. 13), depicts the queen with her left arm stretches across her body to reach the king's left arm above the elbow. ${ }^{2}$ The standing private dual statue of Ptahkhenuwy and his wife (Boston MFA, 06.1876), which dates to the Fifth Dynasty ${ }^{3}$ (Fig. 14), shows the left arm of his wife extends across her body to touch the left arm of her husband below the elbow. The example of the seated figure in royal statues is the most famous and most remarkable triad of Menkaure (Boston MFA, 09.200) (Fig. 15). It depicts Hathor sitting in the middle of the triad; her right arm extends across her body to touch the right arm of the king at the elbow. ${ }^{4}$ The example of the seated figure in private statues is the famous group of Seneb and his family, preserved at the Egyptian Museum in Cairo (JE 51280). ${ }^{5}$ The left arm of Seneb's wife extends across her body to rest on the left arm of her husband at the elbow area (Fig. 16).

Two things are quite different from the scene of the tomb of Baqet III. The arm in all of the above-mentioned examples which extends across the body from the front is not sculpted in a vacuum or negative space. It is always supported by the body of the woman. On the opposite, the right arm of the woman in the tomb of Baqet III is completely depicted in an absolute vacuum without any supporter. Secondly, the external arm of the woman often touches her spouse internal arm at the elbow or slightly above or below (Figs. 13-16). The scene in the tomb of Baqet III shows that the external left arm of the woman touches the internal arm of the man at the wrist and not at elbow. This position, which is not known in the discovered statues, might suggest that the woman shown in this scene was not the wife of the statue owner, as in this case the right position of her arm is at the elbow. Touching the man' arm at the wrist suggests that she was practicing a certain work.

The second hypothesis considers the scene depicting the wife while attending the statue manufacture. This means that the scene embodies a real portrayal of the wife's visit to the Sculptor's Workshop to attend the final stages of making her husband's statue. Although there is no evidence for such visit, which was not known in Egyptian art, a scene in the tomb of Zau (Fig. 8) is considered an evidence by some scholars. "Klebs" ${ }^{6}$ and "Junker"7 suggested that the woman shown in Zau's scene was not a statue, but the wife of the tomb owner during her visit to the sculpture workshop. Their suggestion based on the lack of the base on which the statue usually rests. However, the absence of such pedestal from the statues scenes depicted on the tomb walls was not unusual; the closest evidence is the first of the three scenes on the same wall of Zau's tomb which shows the statue's feet without the base; similar representations are also known in other scenes. ${ }^{8}$ While "Davies", ${ }^{9}$

\footnotetext{
1 Reisner, Mycerinus, 110 (17), pls. 54-60; Reisner, The Harvard University, 19-20.

2 Friedman, The Menkaure dyad(s), 109.

3 PM III, 1, 76; Museum of Fine Arts, Illustrated handbook, 13; Hornemann, Types of Ancient Egyptian Statuary, IV, pl. 1157; Riefstahl and Chapman, "A note on ancient fashions", Fig. 9, 254.

4 Reisner, Mycerinus, 109 (90, pls. 38 (a), 39, 40, 46 (c); Reisner, The Harvard University, 16-17

5 PM III, 1, 102; Saleh and Sourouzian, The Egyptian Museum Cairo, no. 39; Scharff, "On the statuary of the Old Kingdom", pl. x [4], 49-50; Hawass, Inside the Egyptian Museum, 89.

6 Klebs, Die Reliefs des Alten Reiches, 81, note 1.

7 Junker, Stellung der ägyptischen Künstler im Alten Reich, 91-92.

8 Eaton-Krauss, Representation of Statuary, 41, §47, 138.

9 Davies, Deir El Gebrawi, II, 11.
}

A Unique Representation of a Woman in the Scenes of Statue Manufacture 
"Drenkhahn", ${ }^{1}$ and "Hassan", ${ }^{2}$ suggest that this figure represents a statue of Zau's wife. They did not give any explanation. It should be noted that there is a fundamental difference between the figure of the woman in the tomb of Zau and the woman in this study scene. The first woman was depicted in an independent scene, moreover there is no presence of any artisan performing any of the various works usually practiced on the statue while manufacture. Such representation leads to accept any of the views concerning the scene of Zau's tomb, either it represents his wife's visit according to "Klebs" and "Junker", or it depicts his wife statue according to "Davies", "Drenkhahn", and "Hassan". While the scene of this study has portrayed the woman as part of the same manufacture scene, she intertwined with the statue of the man that is being painted, therefore the possibility of explaining this scene as a depiction of the wife's actual visit to the Sculptor's Workshop is the weakest of the three supposed interpretations suggested by this study.

The third hypothesis considers this woman as one of the workers who assist the sculptor in his workshop. Her supposed role was limited to assist the artisan while finishing the painting phase of the statue. So she is shown supporting the statue with both hands, the internal hand supporting it at the shoulder while the external hand supporting it at the wrist, while the artisan, shown sitting on a chair facing the statue, finalizes the painting touches, it is worthy recognizing that this is the only seated artisan in similar painting scenes. The indications of supporting this hypothesis are more than those that weaken it. One indication is the figure of the woman itself. Although she is shown in a similar size to that of the statue, it cannot be overlooked that many of the girls, women, as well as workers depicted in the scenes of this tomb are depicted in the same size (Fig.1). As for her long dress, which is similar to the one worn by the wife of the tomb owner at the beginning of the same wall, it is worn by other girls in various scenes in this tomb, the acrobatic players in the register follows this study scene, are wearing almost the same garment (Fig. 2). It should also be noted that her dress differs from that of the wife in the scene depicted at the beginning of the same wall. The wife's dress fixed to the shoulder by straps whose similar does not appear at the dress of the woman in this study scene. Concerning her accessories, including bracelets and anklets, the other girls in many others scenes in the tomb have similar accessories. Perhaps the most corroborative indication of this interpretation is the position of the two arms of the woman, one of them is touching the shoulder of the statue while the other touching the wrist. This is an unfamiliar situation in the family statues, either dual or group. In such statues, there are various familiar attitudes of the two arms. In some cases, one arm stretches behind the shoulder or the back, while the other touching the arm of the husband near the elbow. (Figs. 13, 14). In some other cases, one arm goes behind the back while the other stretches along the body as shown in a Middle Kingdom double statue kept at the Dublin Museum (Inv. Nr.1901:735) ${ }^{3}$ (Fig. 17). In some other examples, both arms extend along the body as represented in the two Middle Kingdom group statues of Ukhhotep II with his two wives, one group kept at the Boston Museum (MFA, 1973.87) ${ }^{4}$

\footnotetext{
1 Drenkhahn, Die Handwerker, 53.

2 Hassan, Stöcke und Stäbe im Pharaonischen Ägypten, 200.

3 Murray, National Museum of Science and Art, 5.

4 Simpson, "The Middle Kingdom in Egypt", 100-104.
}

- 71 - A Unique Representation of a Woman in the Scenes of Statue Manufacture 
(Fig. 18), and the other at the Egyptian Museum in Cairo (JE 30965). ${ }^{1}$ Although the hand contact at the palm known in some statues, such as the Middle Kingdom dual statue of Nefer-hep and his wife Dedet-nebu kept at the Museum of Natural History in Vienna (Inv. Nr. 5046) ${ }^{2}$ (Fig. 19), the other arm, in this case, is shown extending along the body. This is because the touching hands, in that case, should have been the inner hands of both spouses, which were usually placed over the shoulder or behind the back. While in this study scene, the arm depicted is the outer arm as the internal arm went to the shoulder area. Moreover, the hand contact in this scene is not at the palm but at the wrist. This may lead to suggest that the woman was supporting the statue, and this is the closest possible interpretation that this study is likely to suggest.

\section{CONCLUSION}

According to the attitude of the woman depicted in this study scene, in particular the position of her two arms, this study ends to give preference to the third hypothetical interpretation that suggests that this woman was an artisan working in a sculpture workshop. Her role might have been minimized to the final stages of painting the statue, or at the very least, she was an assistant of the artisan supporting the statue while painting. The absence of similar scenes that confirm this suggestion might have been explained by the very little role played by women or similar assistants during the various stages of statue manufacture. As well as this is the only scene that represents a seated artisan while painting the statue, in other painting scenes he was standing, and when seated he was sculpturing not painting. This scene remains a unique among the Egyptian scenes of statue manufacture as it depicts a female Egyptian artisan, or at the very least a female assistant working in the manufacture of statues.

\footnotetext{
1 Borchardt, Statuen und Statuetten, no. 459, 51-52, pl. 76; Saleh and Sourouzian, The Egyptian Museum Cairo, no. 100; Simpson, "The Middle Kingdom in Egypt", 100-104; PM IV, 257.

2 Jaroš-Deckert, Statuen des Mittleren Reichs, 25-33; Franke, Das Heiligtum des Heqaib auf Elephantine, 78, 289.
} 


\section{REFERENCES}

- Assmann, J., Death and salvation in ancient Egypt, Translated by David Lorton. Ithaca: Cornell University Press, 2005.

- Borchardt, L., Statuen und Statuetten von Königen und Privatleuten im Museum von Kairo, Nr, 11294, (CG; 1-1294), Teil, 2: Text und Tafeln zu Nr. 381-653, Berlin, 1925.

- Davies, N. de G., The Rock Tombs of Deir El Gebrawi, Part I-II, London, 1902. , The Tomb of Rekh-mi-re at Thebes, Vol. II, New York, 1943.

- Davis, W., "Scale and Pictoriality in Ancient Egyptian Painting and Sculpture", Art History 38, 2 (2015), 268-285.

- Drenkhahn, R., Die Handwerker und ihre Tätigkeiten im Alten Ägypten, Ägyptologische Abhandlungen 31, Wiesbaden, 1976.

- Dunham, D. and Simpson, W. K., The Mastaba of Queen Mersyankh III, Boston, 1974.

- Eaton-Krauss, M., "Sculpture in Early Dynastic Egypt", In: Patch, D., (ed.), Dawn of Egyptian Art, New York, 2011, pp. 180-193.

- The Representation of Statuary in Private tombs of the Old Kingdom, Ägyptologische Abhandlungen 39, Wiesbaden, 1984.

- Eiwanger, J., "Die neolithische Siedlung von Merimde-Benisalâme: Vierter Bericht", MDAIK 38 (1982), 67-82.

- Finnestad, R., "The meaning and purpose of Opening the Mouth in mortuary contexts", Numen 25 (2) (1978), 118-134.

- Franke, D., Das Heiligtum des Heqaib auf Elephantine: Geschichte eines Provinzheiligtums im Mittleren Reich, SAGA 9, Heidelberg, 1994.

- Friedman, F. D., “The Menkaure dyad(s)", In: S.E. Thompson, and P. Der Manuelian (eds), Egypt and beyond: essays presented to Leonard H. Lesko upon his retirement from the Wilbour chair of Egyptology at Brown University June 2005, Brown University, 2008, 109-144.

- Hassan, A., Stöcke und Stäbe im Pharaonischen Ägypten bis zum Ende des Neuen Reiches, MÄS 33. Munich/ Berlin, 1976.

- Hawass, Z., Inside the Egyptian Museum with Zahi Hawass, Cairo, 2010.

- Hornemann, B., Types of Ancient Egyptian Statuary IV-V, Copenhagen, 1966.

- Jaroš-Deckert, B., Kunsthistorisches Museum Wien, Lieferung 1: Statuen des Mittleren Reichs und der 18. Dynastie. Corpus antiquitatum Aegyptiacarum, Mainz am Rhein: Philipp von Zabern, 1987.

-Junker, H., Die gesellschaftliche Stellung der ägyptischen Künstler im Alten Reich, SÖAW 233:1. Vienna, 1959.

- Klebs, L., Die Reliefs des Alten Reiches (2980-2475 v. Chr.): Material zur ägyptischen Kulturgeschichte, Heidelberg, 1915.

- Kozloff, A., "Sculpture: An Overviesw", In: D. Redford (ed.), The Oxford Encyclopedia of Ancient Egypt, vol. 3, Cairo, 2001, 218-228.

- Lorton, D., "The Theology of Cult Statues in Ancient Egypt", In: M. Dick (ed.), Born in heaven, made on earth: the making of the cult image in the ancient Near East, Winona Lake: Eisenbrauns, 1999, 123-210.

- Murray, M. A., National Museum of Science and Art, General Guide III. Egyptian Antiquities, Dublin, 1910.

- Museum of Fine Arts, Illustrated handbook: Museum of Fine Arts, Boston, 1920.

- Newberry, P.E., Beni Hasan, Part I, London, 1893.

- _. Beni Hasan, Part II, London, 1893.

- Otto, E., Das Ägyptische Mundöffnungsritual, Ägyptologische Abhandlungen 3, Wiesbaden, 1960.

- Porter, B. and Moss, R.L., Topographical Bibliography of Ancient Egyptian Hieroglyphic Texts, Reliefs and Paintings, Vols. I, III, IV, Oxford, 1970, 1974, 1986.

- Price, C., "On the function of 'healing' statues", in: C. Price et al (eds.), Mummies, Magic and Medicine in Ancient Egypt Multidisciplinary Essays for Rosalie David, Manchester, 2016, 169-182.

- Reisner, G., "The Harvard University: Museum of Fine Arts Egyptian Expedition", BMFA 9, No. 50 (Apr. 1911), 13-20.

- 73 - A Unique Representation of a Woman in the Scenes of Statue Manufacture 
- Reisner, G., "The Tomb of Meresankh, a Great-Granddaughter of Queen Hetep-Heres Iand Seneferuw", BMFA 25, No. 151, (1927), 64-79.

- Reisner, G., Mycerinus: the temples of the Third Pyramid at Giza, Cambridge, MA: Harvard University Press, 1931.

- Riefstahl, E. and Chapman, S. E., "A note on ancient fashions: four early Egyptian dresses in the Museum of Fine Arts, Boston”, BMFA 68, No. 354 (1970), 244-259.

- Robins, G., The Art of Ancient Egypt, Cambridge, 2008.

- Saleh, M. and Sourouzian, H., The Egyptian Museum Cairo: official catalogue, Mainz: Zabern, 1987.

- Scharff, A., "On the statuary of the Old Kingdom", JEA 26 (1941), 41-50.

- Simpson, W. K., "The Middle Kingdom in Egypt: Some Recent Acquisitions", BMFA 72, No. 368 (1974), 100-116.

- Tefnin, R., "Sculpture: Private Sculpture", In: D. Redford (ed.), The Oxford Encyclopedia of Ancient Egypt, vol. 3, Cairo, 2001, 235-242.

- Wild, H., Le tombeau de Ti. la chapelle (deuxieme partie), MIFAO 65.3, Le Caire, 1966.

- Ziegler, Ch., "Nonroyal Statuary", In: Anonymous (ed.), Egyptian Art in the Age of the Pyramids, New York: Metropolitan Museum of Art, 1999, 56-71. 


\section{PLATES}

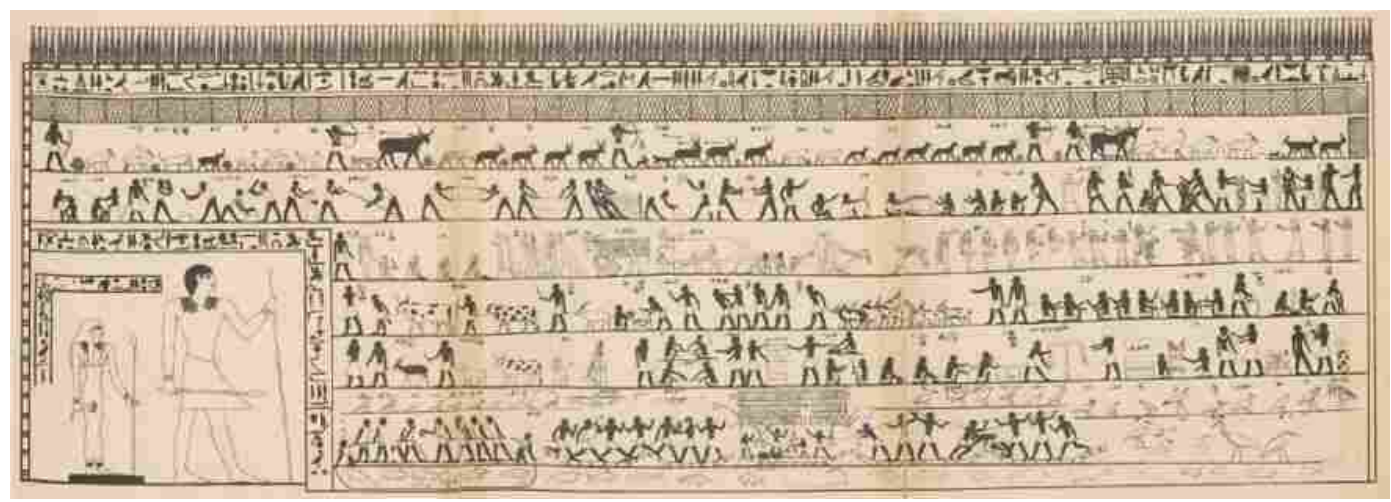

Fig. (1) Scenes on the northern wall of the tomb of Baqet III. (Newberry, Beni Hasan, II, pl. iv)

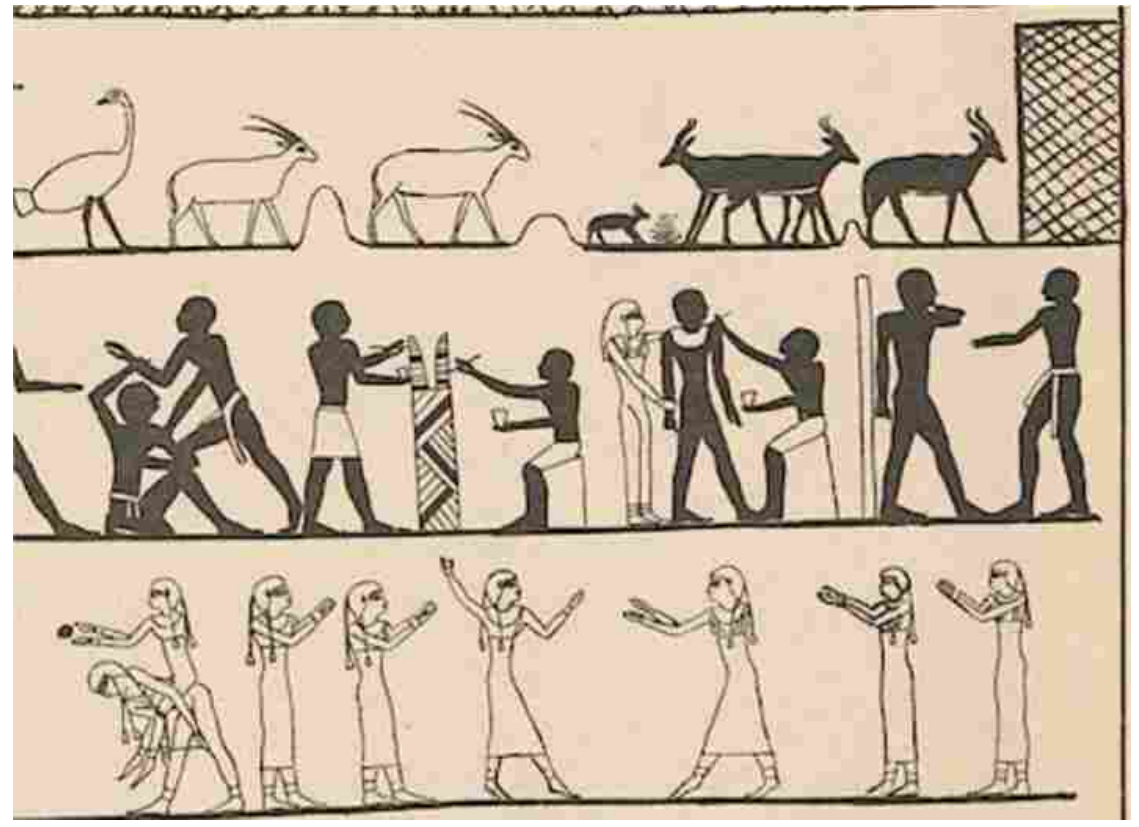

Fig. (2) Details from the previous scene. (Newberry, Beni Hasan, II, pl. iv)

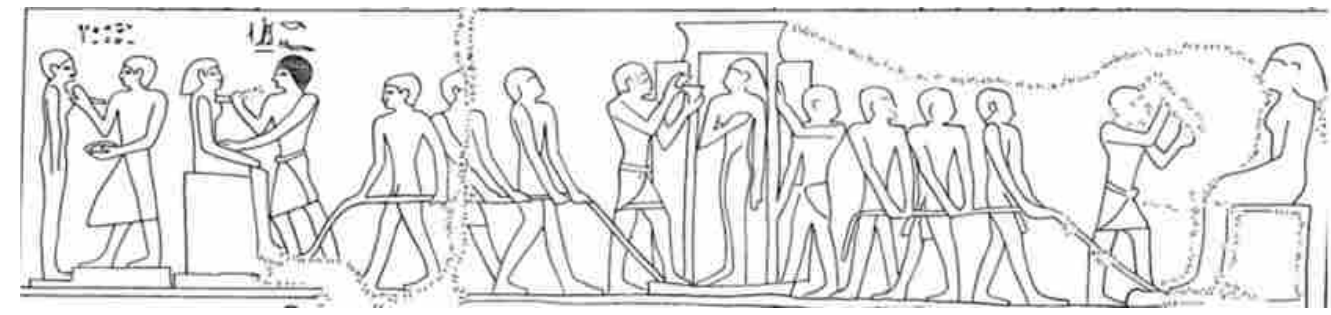

Fig. (3) Statue making at the tomb of Mersyankh III. (Dunham and Simpson, Mersyankh, Fig.5)

\footnotetext{
- 75 - A Unique Representation of a Woman in the Scenes of Statue Manufacture
} 


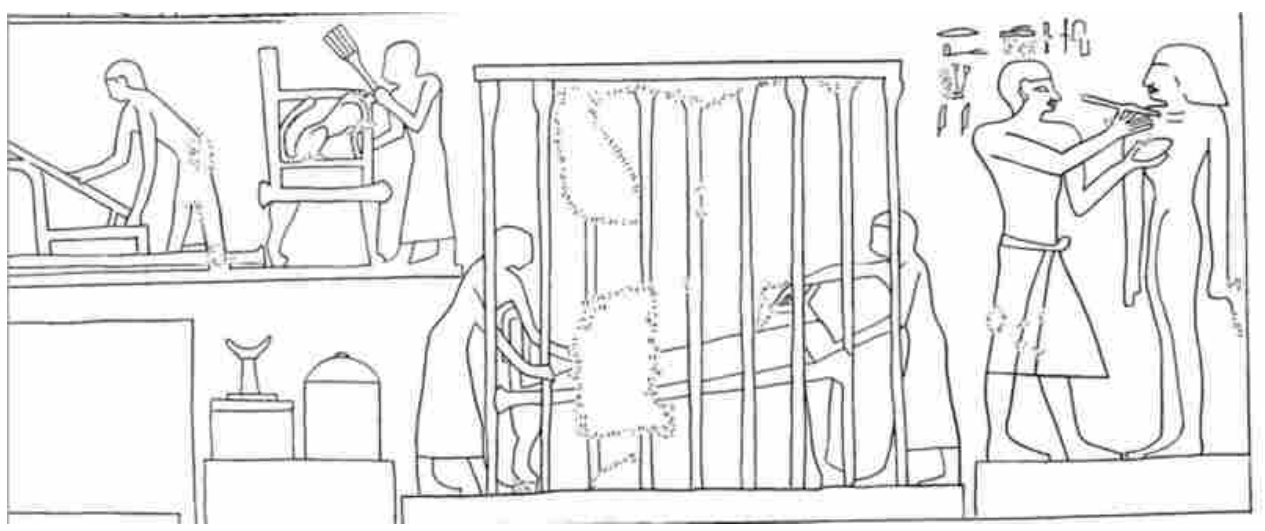

Fig. (4) Statue making at the tomb of Mersyankh III.

(Dunham and Simpson, Mersyankh, fig.8)

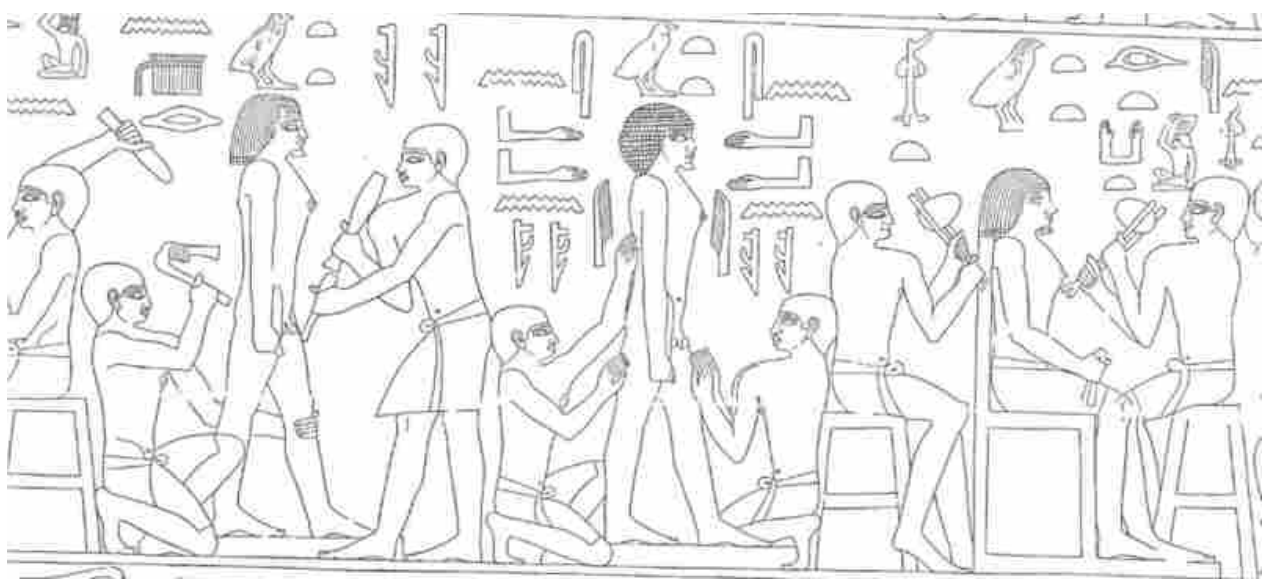

Fig. (5) Scenes of statue making at the tomb of Ti.

(Wild, Le tombeau de Ti, III, pl. clxxiii)

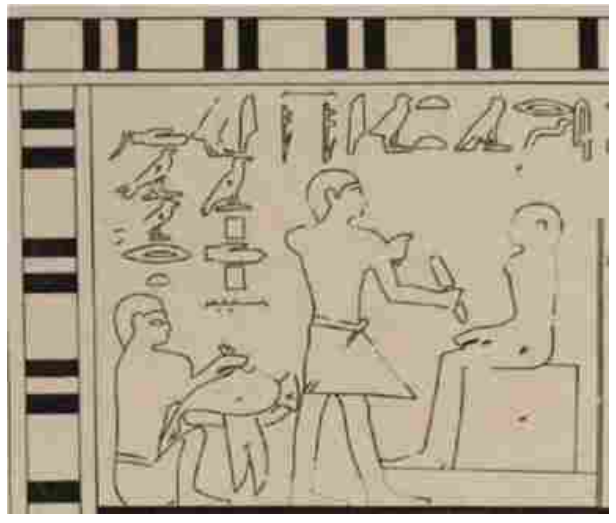

Fig. (6) A scenes of statue making at the tomb of Aba. (Davies, Deir El Gebrawi, I, pl. xiv) 


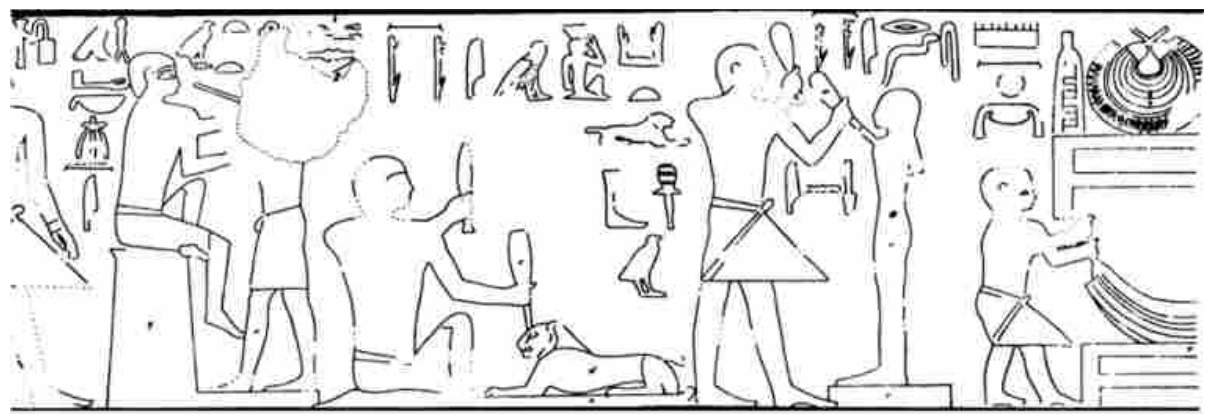

Fig. (7) Scenes of statue making at the tomb of Aba.

(Davies, Deir El Gebrawi, I, pl. xiv)

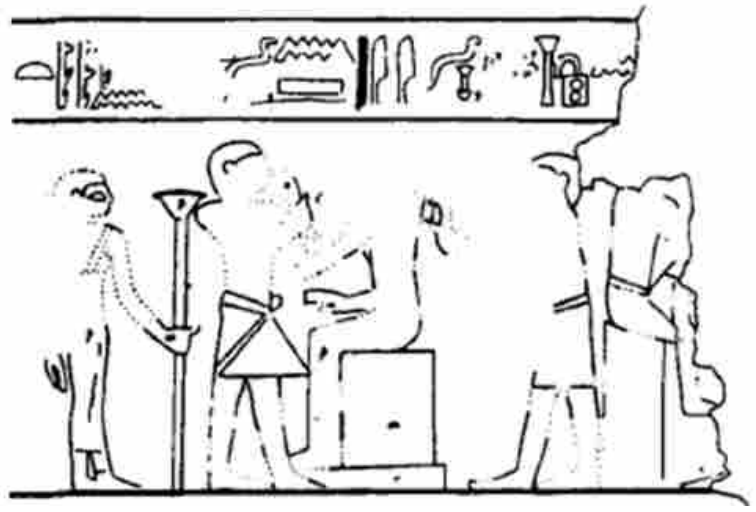

Fig. (8) Scenes of statue making at the tomb of Zau. (Davies, Deir El Gebrawi, II, pl. x)

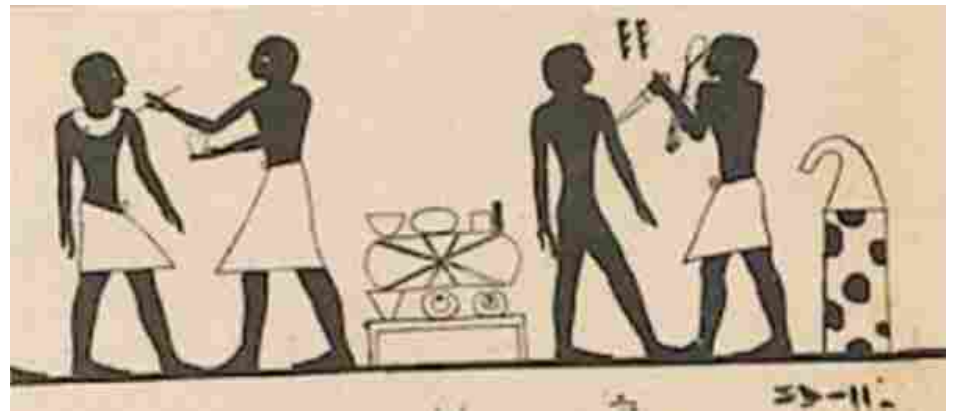

Fig. (9) Scenes of statue making at the tomb of Baqet III. (Newberry, Beni Hasan, II, pl. iv) 


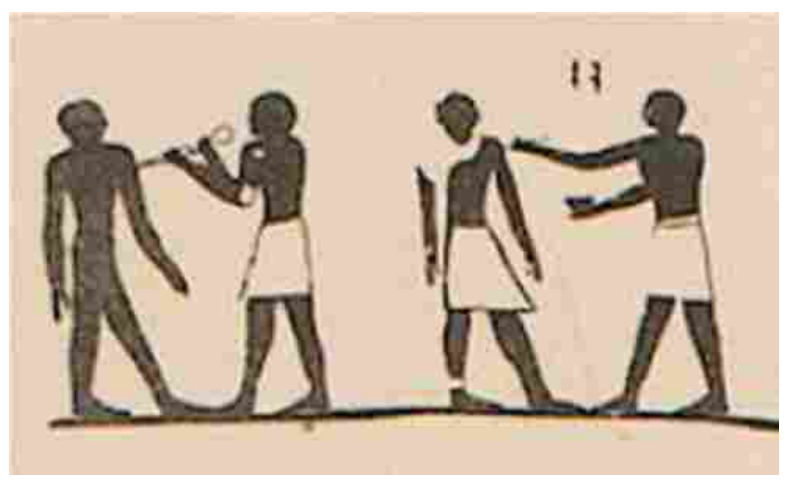

Fig. (10) Scenes of statue making at the tomb of Khety. (Newberry, Beni Hasan, II, pl. xiii)

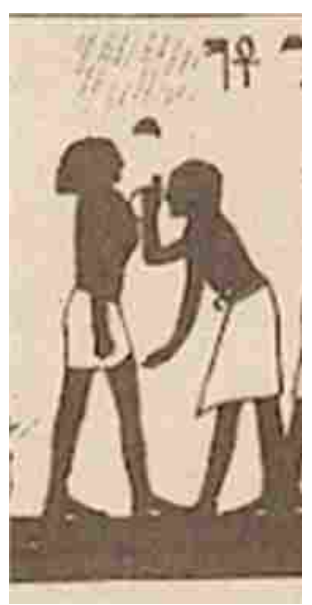

Fig. (11) A scene of statue making at the tomb of Khnumhotep. (Newberry, Beni Hasan, I, pl. xxix)

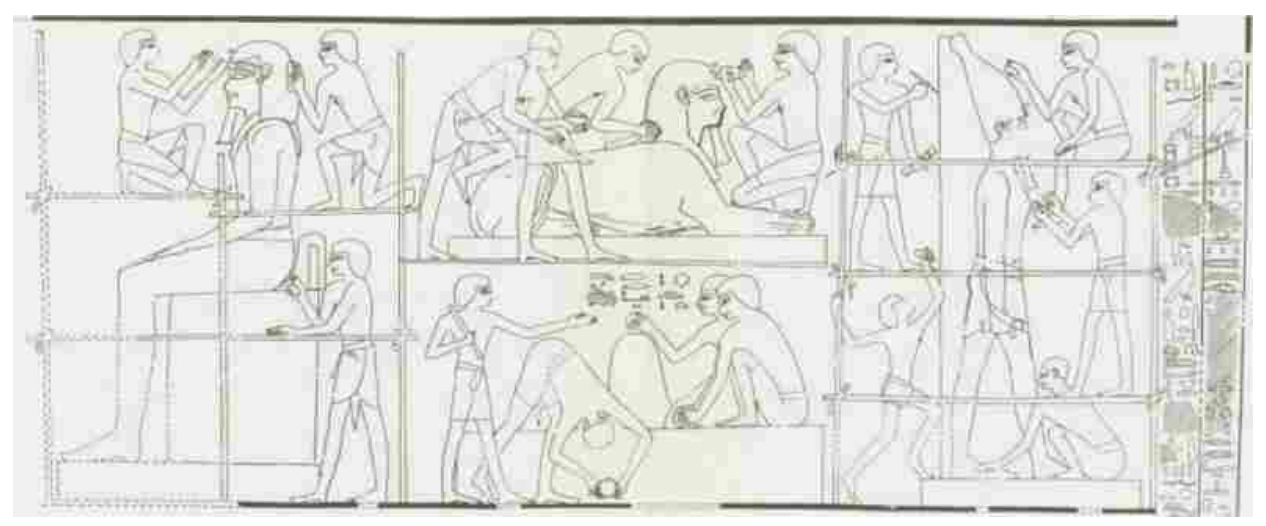

Fig. (12) Scenes of statue making at the tomb of Rekhmire. (Davies, The Tomb of Rekh-mi-re, pl.Ix) 


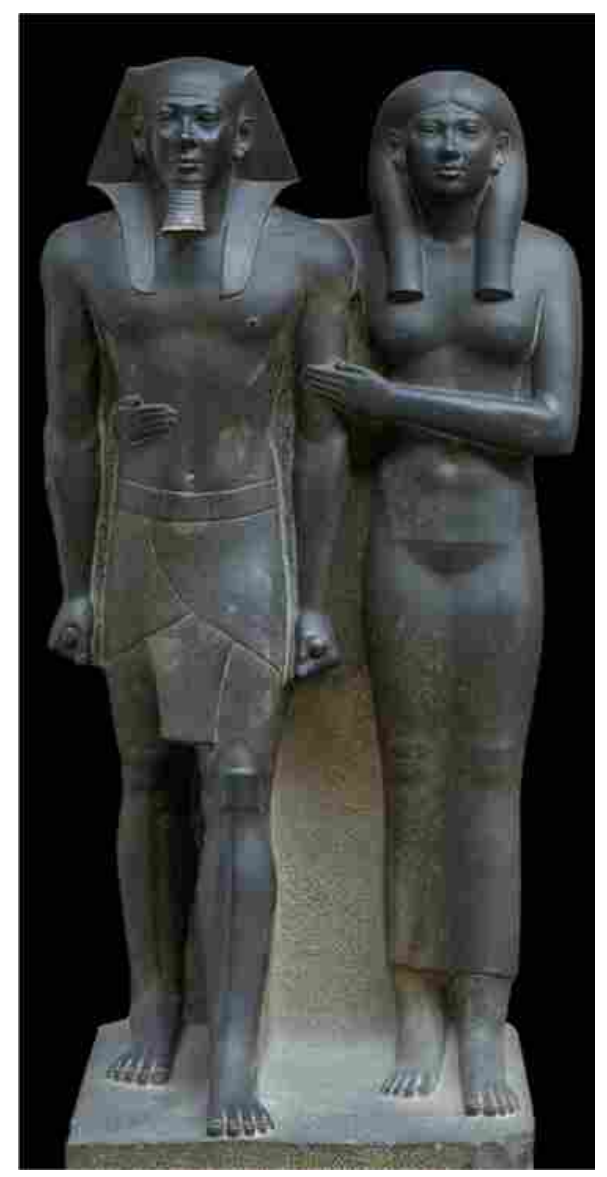

Fig. (13) Pair statue of Menkaure and his wife. (www.mfa.org/collections/object/kingmenkaura-mycerinus-and-queen-230)

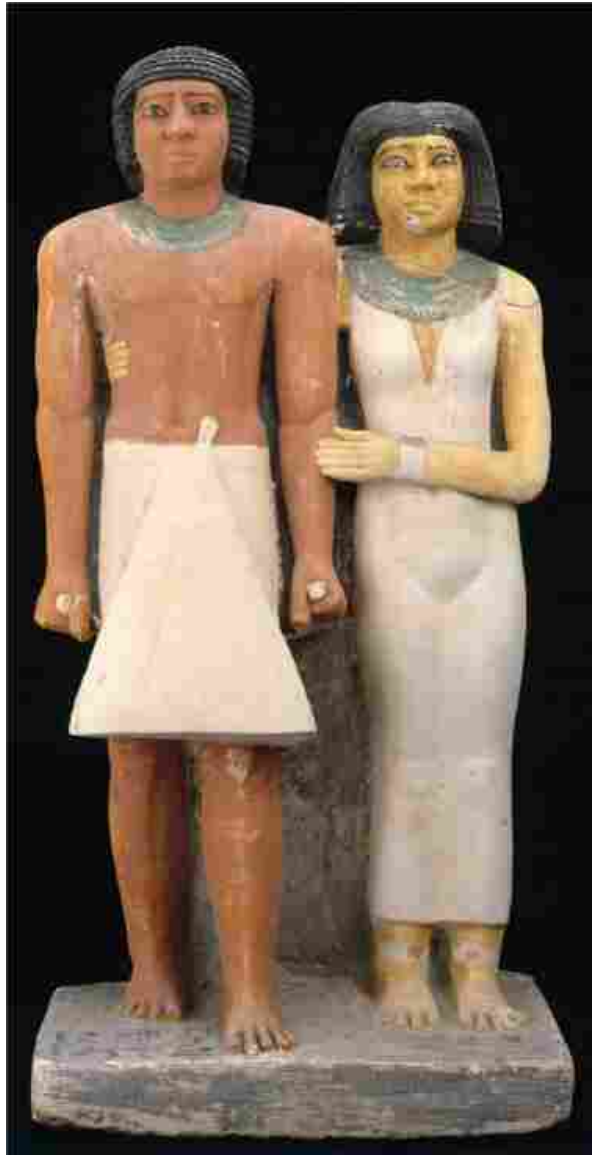

Fig. (14) Pair statue of Ptahkhenuwy and his wife. (www.mfa.org/collections/object/pair-statueof-ptahkhenuwy-and-his-wife-137139)

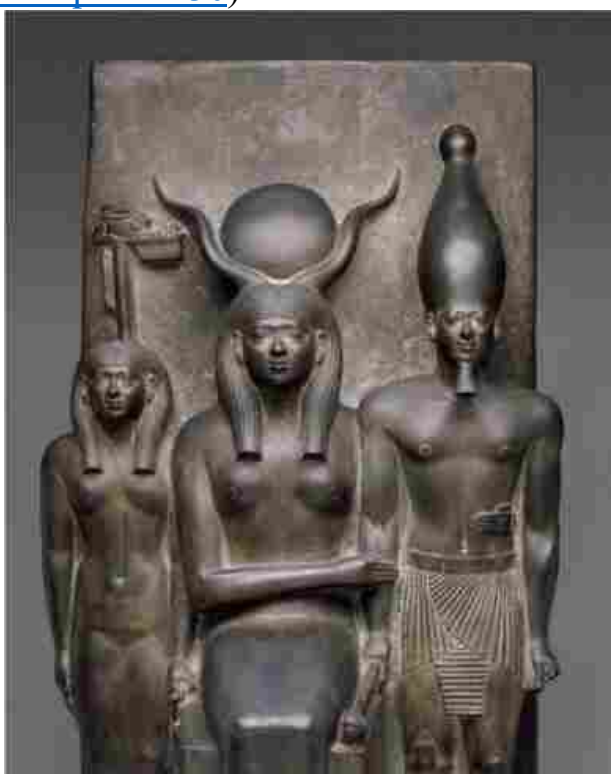

Fig. (15) Triad of Menkaure

. (www.mfa.org/collections/object/king-menkaura-the-goddess-hathor-and-the-deifiedhare-nome-138424)

\footnotetext{
- 79 - A Unique Representation of a Woman in the Scenes of Statue Manufacture
} 


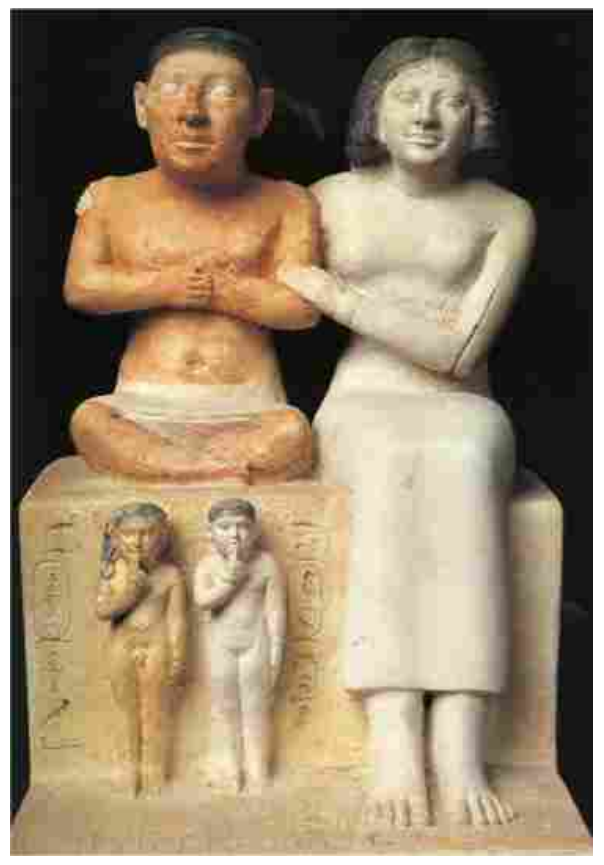

Fig. (16) Group statue of Seneb and his family. (Hawass, Inside the Egyptian Museum, 89)

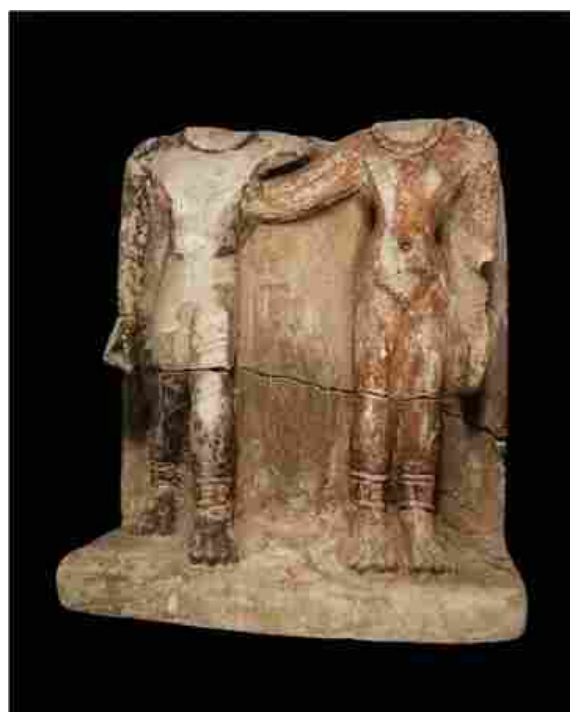

Fig. (17) A Middle Kingdom dual statue.

(www.globalegyptianmuseum.org/detail.aspx?id=1970) 


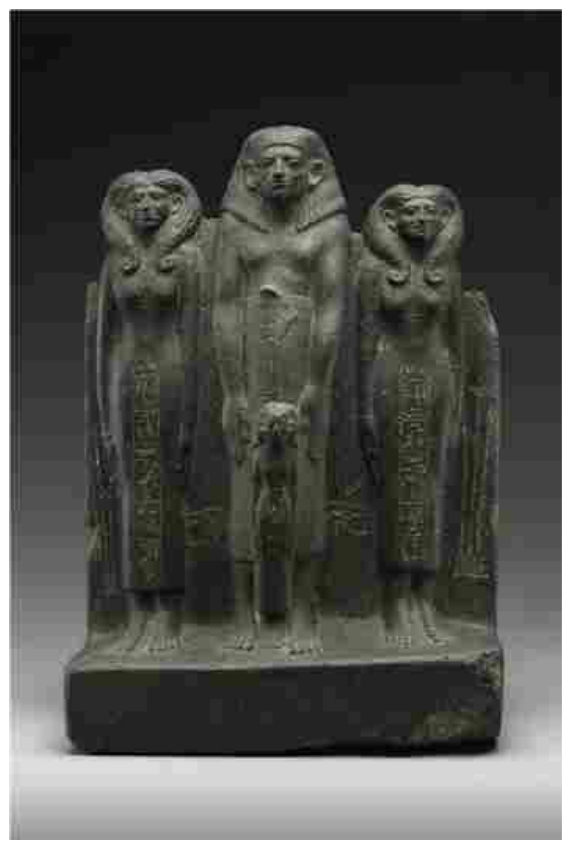

Fig. (18) Group statue of Ukhhotep II and his family.

(www.mfa.org/collections/object/group-statue-of-ukhhotep-ii-and-his-family-164286)

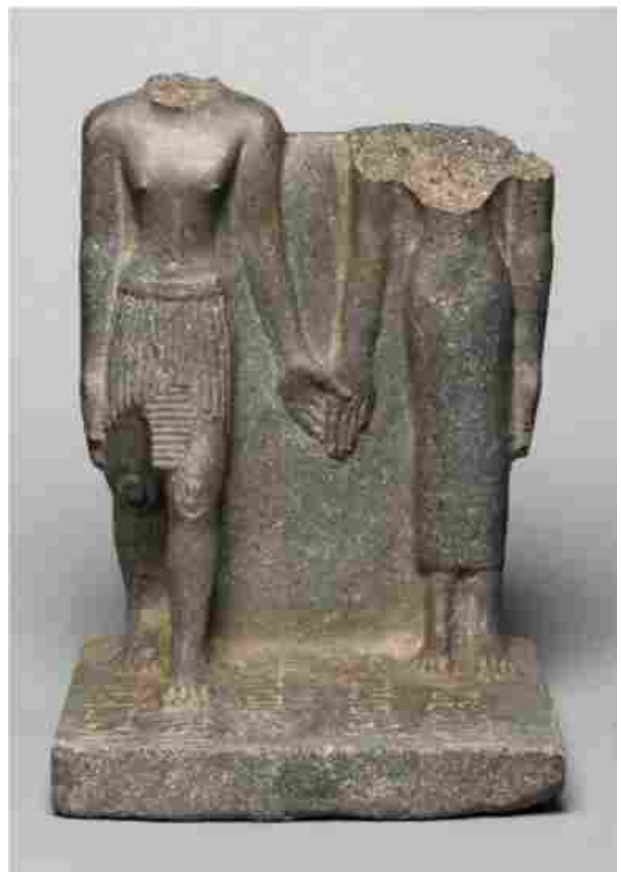

Fig. (19) Pair statue of Nefer-hep and his wife.

(www.khm.at/objektdb/detail/319706/?offset $=6 \& l v=$ list)

\footnotetext{
- 81 - 1 A Unique Representation of a Woman in the Scenes of Statue Manufacture
} 